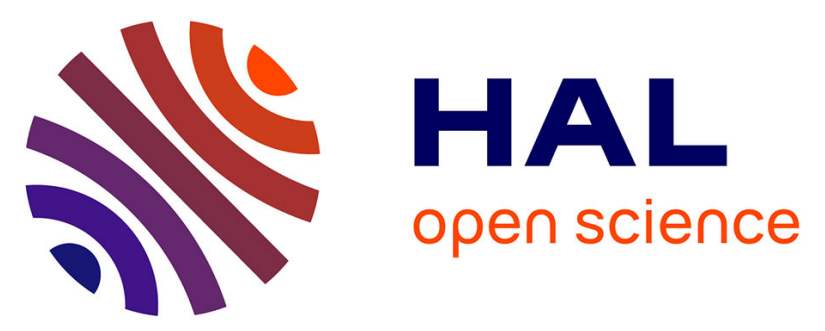

\title{
Modeling of a Continuous Anaerobic Digestion of Wastes
} Younoussa Moussa Balde, Sihem Tebbani, Sette Diop, Cellou Kante

\section{To cite this version:}

Younoussa Moussa Balde, Sihem Tebbani, Sette Diop, Cellou Kante. Modeling of a Continuous Anaerobic Digestion of Wastes. 2020 24th International Conference on System Theory, Control and Computing (ICSTCC), Oct 2020, Sinaia (virtual ), Romania. pp.596-601, 10.1109/ICSTCC50638.2020.9259735 . hal-03034724

\section{HAL Id: hal-03034724 \\ https://hal.science/hal-03034724}

Submitted on 1 Dec 2020

HAL is a multi-disciplinary open access archive for the deposit and dissemination of scientific research documents, whether they are published or not. The documents may come from teaching and research institutions in France or abroad, or from public or private research centers.
L'archive ouverte pluridisciplinaire HAL, est destinée au dépôt et à la diffusion de documents scientifiques de niveau recherche, publiés ou non, émanant des établissements d'enseignement et de recherche français ou étrangers, des laboratoires publics ou privés. 


\section{Modelling of a Continuous Anaerobic Digestion of Wastes}

\author{
Younoussa Moussa Baldé \\ Université Paris-Saclay, CNRS, CentraleSupélec \\ Laboratoire des Signaux et Systèmes \\ 91190, Gif sur Yvette, France \\ youmoussa.balde@12s.centralesupelec.fr \\ Sette Diop \\ Université Paris-Saclay, CNRS, CentraleSupélec \\ Laboratoire des Signaux et Systèmes \\ 91190, Gif sur Yvette, France \\ sette.diop@12s.centralesupelec.fr
}

\author{
Sihem Tebbani \\ Université Paris-Saclay, CNRS, CentraleSupélec \\ Laboratoire des Signaux et Systèmes \\ 91190, Gif sur Yvette, France \\ sihem.tebbani@centralesupelec.fr \\ Cellou Kanté \\ Energy and Environment \\ LEREA/UGANC,University of Conakry \\ Mamou, Guinea \\ celkante@yahoo.fr
}

\begin{abstract}
Anaerobic digestion is widely used for waste treatment and the production of biogas. The automatization and optimization of the operation of the digestor is still a challenging task. This study considers the first step in the design of the optimal continuous operation of an experimental anaerobic digestor, namely its modeling. The well-known Anaerobic Digestion Model No.1 (ADM1) model is used, and its parameters identified from experimental data. Sensitivity analysis allows determining the more influential kinetic parameters of the model to be identified. The modeling procedure is assessed and its performance highlighted through the comparison between measured and predicted outputs.
\end{abstract}

Index Terms-Anaerobic digestion, biogas, modelling, identification, sensitivity analysis.

\section{INTRODUCTION}

Anaerobic digestion (AD) is a natural process of transforming organic matter into energy by bacteria in the absence of oxygen [1]. The digestion is conducted in confined chambers (called digesters) inside which the fermentation reactions are optimized and controlled. Biogas, mainly composed of methane, is produced while reducing by half the organic matter content of many biodegradable wastes or by-products. The residue from digestion (or digestate) is stable, deodorized, mostly free of pathogenic germs [1]. This kind of energy production, widely used and known for ages, presents a very promising solution for renewable energy production. It, however, raises some challenges linked to the operation of this kind of complex, uncertain systems [2], [3].

Indeed, anaerobic digestion is a multistage process in which a consortium of microorganisms acts upon composite organic matter to produce biogas $\left(\mathrm{CH}_{4}, \mathrm{CO}_{2}, \mathrm{H}_{2}\right.$, and $\left.\mathrm{H}_{2} \mathrm{~S}\right)$ [4]. The monitoring and control of an $\mathrm{AD}$ process, in order to maintain stable and optimal system operation, is a difficult task because of the complexity of the system and of the lack of online sensors for biological and biochemical variables. Mathematical modeling of the AD process is the first step in its automatization. The model will be used in a second step to develop simulation models to test and assess estimation and control strategies [5], [6]. In this context, benchmark simulation models (BSMs) have been designed to develop, test, and evaluate local and/or plant wide wastewater treatment plant control and monitoring strategies, using dynamic models to realize good effluent quality at low operational cost [7]. Several model were proposed in the literature to model the $\mathrm{AD}$ process [8]-[10]. Among the models presented in the literature, the Anaerobic Digestion Model No.1 (ADM1), proposed in [9] is probably the most used one. ADM1 model has been tested in several applications such as municipal sewage sludge and solid waste, agricultural waste, livestock waste, and crop residues. ADM1 is a structured model, where physical, chemical, and biological processes are embedded in a kinetic biochemical matrix. A total of 19 biochemical processes are included such as disintegration, hydrolysis, acidogenesis, acetogenesis, and methanogenesis [9].

In this study, the ADM1 model is used to model an experimental AD system for cow dung. More specifically, the paper presents the ADM1 calibration and parameter identification for the studied experimental biodigester. The proposed procedure was developed as an analogy to aerobic respirometry used for the determination of influent COD fractions for activated sludge system models [11]. This procedure enables the simultaneous determination of some ADM1 input state variables and related hydrolysis kinetics [11].

In this paper, the kinetic parameters of the reactions of the decay, acetogenesis, and methanogenesis processes during anaerobic digestion are verified. Simulation results are then compared with some experimentally obtained data, namely biogas/methane production, chemical oxygen demand (COD) concentration, volatile fatty acid (acetate, propionate and valerate) concentration [12].

This paper represents the first step for the modeling, estimation and control of the studied experimental biodigestor.

The paper is structured as follows. First, the process and 
its modeling are presented in Section 1. Secondly, the identification procedure is detailed in Section 2. Experimental results are presented and discussed in Section 3. Finally, the conclusion and perspectives conclude the paper.

\section{SYSTEM MODELING}

\section{A. Experimental setup}

The simulation was carried out on the basis of data collected (1) from an experimental biodigestor built at the Superior Institute of Technology of Mamou (Guinea) (see Fig. 1).

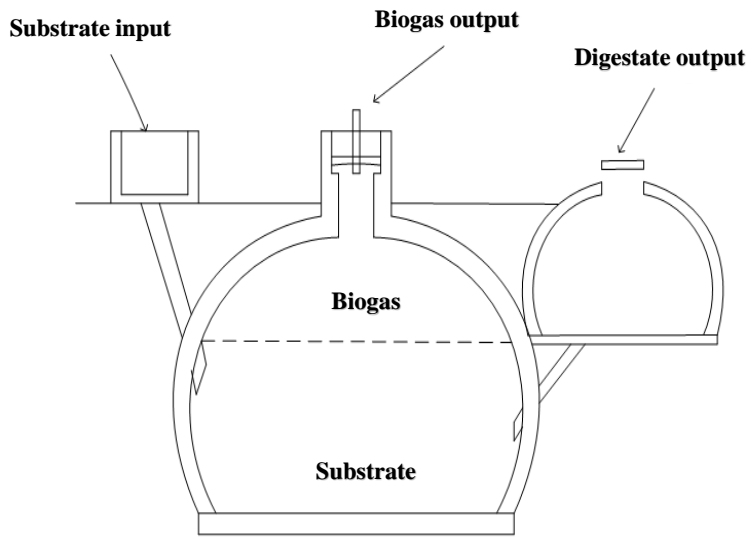

Fig. 1. Schematic representation of the studied anaerobic digestor

The bioreactor has a volume of $3 \mathrm{~m}^{3}$, operating under mesophilic conditions at $35^{\circ} \mathrm{C}$. The liquid volume varies between $1.5 \mathrm{~m}^{3}$ and $2 \mathrm{~m}^{3}$ and the hydraulic retention time (HRT, or residence time) is about 45 days. It represents the duration that a soluable compound remains in bioreactor.

The digester is fed with $35 \mathrm{~kg}$ of raw material, cow dung in our study. The average inflow load is $0.34 \mathrm{~kg} \cdot \mathrm{m}^{-3}$. The average biogas production is about $2.1 \mathrm{~N} \cdot \mathrm{m}^{3} \mathrm{~d}^{-1}$ ( $\mathrm{d}$ : day), and

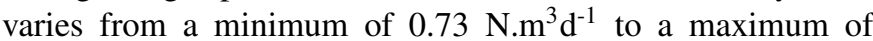
$2.49 \mathrm{~N} \cdot \mathrm{m}^{3} \mathrm{~d}^{-1}$.

The bioreactor is agitated everyday and the culture medium will be assumed to be homogeneous hereafer.

The characterization of the physical and biomechemical variables, namely dry matter (DM), organic matter (OM) and chemical oxygen demand (COD) are based on standard methods. Volatile fatty acids (VFA) were measured using a gas chromatograph.

Determination methods according to [13], [14], were used to characterize the substrate in terms of carbohydrates, proteins and fats [14].

The total biogas production was measured by the Itron/G4 GALLUS gas meter. The values of the biogas production were normalized. Biogas production, the distribution of the main biogas components $\left(\mathrm{CH}_{4}\right.$ and $\left.\mathrm{CO}_{2}\right)$, temperature and $\mathrm{pH}$ were measured continuously throughout the experiment period.

The measurements of COD, VFA and biogas flow rate will be used hereafter for the model identification.

\section{B. Mathematical modeling}

The ADM1 model is a high-order nonlinear model widely used to model the anaerobic digestion.

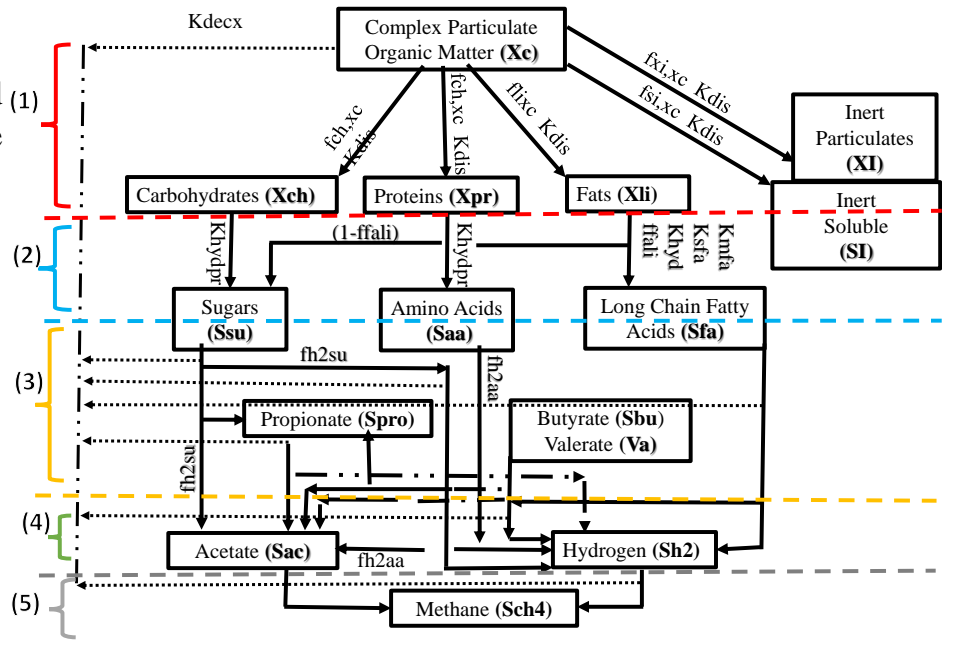

Fig. 2. Schematic representation of anaerobic digestion. (1) Desintegration, (2) Hydrolysis, (3) Acidogenesis, (4) Acetogenesis, (5) Methanogenesis.

In the ADM1 model, anaerobic digestion is divided into five basic processes, namely the desintegration, hydrolysis, acidogenesis, acetogenesis and methanogenesis (see Fig. 2).

All extracellular biochemical processes are assumed to be first-order type, while all intracellular reactions are Monodtype kinetics.

The influent chemical oxygen demand (COD) is split into 13 input state variables including 11 biodegradable COD fractions such as composite substrate, carbohydrates, proteins, lipids, sugars, amino acids, long chain fatty acids, butyrate, valerate, propionate and acetate. Inert COD of the influent is split into a soluble fraction and a particulate fraction [15]. Every substrate was considered as composed of fractions which degrade at different rates. Particulate fractions have by definition hydrolysis as limiting rate and therefore their rate of degradation was described by a first order hydrolysis kinetics [16].

In this study, a modified version of the ADM1 model as in [17] is considered. This modified version incorporates the concentration of particulate products arising from biomass decay in the state vector.

The ADM1 model is then described via a set of ordinary differential equations (ODE) and of algebraic differential equations (DAE). The ODE equations, about 35 equations, are derived from dynamics of state variable corresponding to a component in the liquid phase. It is determined from a mass balance consideration assuming a continuous well stirred-tank reactor. In [18], some ODE equation can be replaced by algebraic differential equations (DAE). The DAE equations concern 33 steady-state variables (substrates, reaction intermediates and gaseous products, i.e. methane, hydrogen, carbon 
dioxide in the liquid and gaseous phase). The model includes 105 stoichiometric and kinetic parameters.

The MATLAB/SIMULINK software proposed by [9] and [18] was used as the simulation tool in this study.

\section{MODEL CALIBRATION}

\section{A. Input flow-rate}

First of all, the input flow rate of the waste, here cow dung, must be determined. The digestor is operated in continuous mode (outlet flow-rate equals its inlet, leading to a constant cultivation volume). This flow rate must be sufficient to allow the growth of bacterial populations, but not too high to avoid growth inhibition by the sustrate or a culture washout.

In this study, the inlet flow rate was determined experimentally, via the determination of the dilution rate (denoted $D$ ). The latter is defined as the inverse of the HRT. It can be also defined as:

$$
D=\frac{Q_{i n}}{V_{l i q}}
$$

Where $Q_{i n}$ is the feed-rate (in $\mathrm{m}^{3} \cdot \mathrm{d}^{-1}$ ), $V_{L i q}$ is the volume of liquid (in $\mathrm{m}^{3}$ ) and $D$ is the dilution ratio (in $\mathrm{d}^{-1}$ ).

For the determination of the appropriate value of the dilution rate for the identification procedure, several experiments were carried out (see Section IV). Anaerobic digestion experiments were performed for several values of dilution rate, over periods of 45 days.

\section{B. Model parameters determination}

From available experimental measurements of gas flow rate, VFA and DCO concentrations, model parameters are adjusted so that the experimental data are as close as possible to the predicted values with the ADM1 model. However, ADM1 model is a high-order nonlinear model, making the model calibration a difficult task. In this study, the model parameters were divided into two groups. The first group contains less influential parameters. Their value will be fixed from the literature. The second group of parameters represents the most influential model parameters on the system output. They will then be identified from the measured data. The model parameters to be identified are then determined by solving an optimization problem. The optimal value of parameters' values, $\Theta^{*}$, minimizes the following cost function:

$$
J=\left\|y-y_{p}\right\|_{Q}^{2}
$$

where $y$ and $y_{p}$ are measured and predicted data of gas flow rate, VFA, and DCO concentrations, respectively, the matrix $Q$ is a normalization matrix. Bound constraints could be added to this optimization problem, e.g. to constrain each $\Theta$ component to be positive.

The determination of the influence of the parameters on the outputs were determined thanks to a sensitivity analysis.

In order to define which parameter can influence the most a defined variable, a sensitivity analysis of the outputs with respect to the parameters must be performed. Relative Sensitive Function (RSF) proposed in [19] is used. It is defined as:

$$
\delta_{i, j}=\frac{P_{i}}{y_{j}\left(P_{i}\right)} \frac{y_{i}\left(P_{i}+\Delta P_{i}\right)-y_{j}\left(P_{i}\right)}{\Delta P i}
$$

where $\delta_{i, j}$ is the RSF between $P_{i}$ and $y_{j}, P_{i}$ the $i^{\text {th }}$ parameter, $y_{j}\left(P_{i}\right)$ the $j^{\text {th }}$ output, $\Delta P_{i}$ the variation on the parameter. A value up to $20 \%$ for $\Delta P_{i}$ is commonly used. In this study, the parameter variation, $\Delta P_{i}$, is determined from the range of ordre of the parameter from the literature for similar application.

The value of RSF will help to determine the influnce of parameter $i^{t h}$ on the $j^{t h}$ output [19]:

- RSF < 0.25: No influence, denoted "0"

- $0.2 \leq \mathrm{RSF}<1$ : Sensitive, denoted "+"

- $1 \leq \mathrm{RSF}<2$ : Very sensitive, denoted "++"

- $\mathrm{RSF} \geq 2$ : Extremely sensitive, denoted "+++"

For each parameter of the ADM1 model, the RSF value for all the outputs is calculated to determine the most influential parameters for each output.

It should be mentionned that one parameter can influence several state variables, just as it can be found that several parameters can influence the same state variable. Some adjustable parameters are shown in Fig. (2).

The influence of the parameters on the outputs also highly depends on the operating conditions. For example, in the case of inhibition conditions, parameters linked to the kinetics of inhibition are the most influencial ones. On the contrary, if the system is operated far from inhibition conditions, these inhibition parameters have less influence on the outputs. It is then important to perform sensitivity analysis for operating conditions close to the optimal ones (since in our case the process will be operated later in the optimal conditions), or for several inputs to caracterize the influence of parameters for several case studies.

However, the parameter identification of a biological model can be a difficult task, especially since there are few measured data. In this study, we choose to limit the identification to biochemical parameters only. The stoichoimetric parameters will be either fixed to a value from the literature for similar AD processes, or to the default value of ADM1 model if their influence, for the considered inlet flow rate, is very small. In addition, the decay rates for all acetogens were increased to $0.04 \mathrm{~d}^{-1}$ in agreement with other research indicating decay rates higher than $0.02 \mathrm{~d}^{-1}$ [20]. In the next section, the results obtained by applying the proposed procedure are detailed and analyzed.

\section{EXPERIMENTAL RESULTS}

\section{A. Input flow-rate}

The input flow rate was chosen with a piecewise constant evolution as illustrated by Fig. 3. The dilution rate of the substrate varies from a minimum of $0.2 \mathrm{~d}^{-1}$ to a maximum of $0.25 \mathrm{~d}^{-1}$, with a progressive change in average of $0.02 \mathrm{~d}^{-1}$. 
TABLE I

Dilution RATE VALUES.

\begin{tabular}{|c|c|c|c|}
\hline Time & $\boldsymbol{D}\left(\boldsymbol{d}^{-\boldsymbol{1}}\right)$ & Time & $\boldsymbol{D}\left(\boldsymbol{d}^{-\boldsymbol{T}}\right)$ \\
\hline 0 & 0.252 & 22 & 0.216 \\
\hline 2 & 0.252 & 23 & 0.253 \\
\hline 3 & 0.186 & 34 & 0.253 \\
\hline 8 & 0.186 & 35 & 0.223 \\
\hline 9 & 0.238 & 39 & 0.223 \\
\hline 15 & 0.238 & 40 & 0.200 \\
\hline 16 & 0.216 & 45 & 0.200 \\
\hline
\end{tabular}

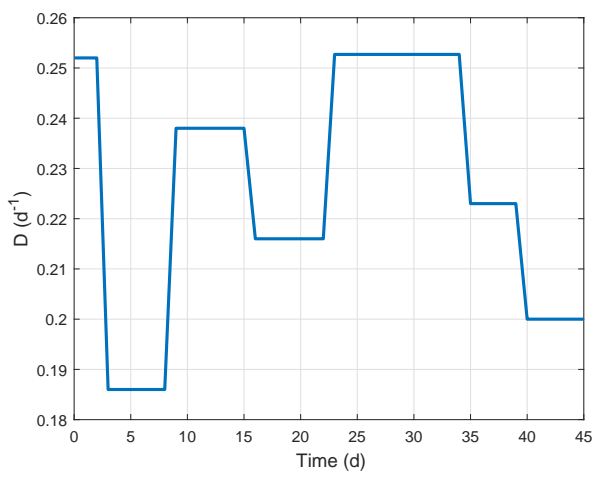

Fig. 3. Dilution rate evolution versus time.

\section{EXPERIMENTAL BIOGAS PRODUCTION RESULTS}

Figure (4) illustrates the measured gaz flow rate. It can be noticed that the transformation into gaseous compounds $\mathrm{CO}_{2}$ and $\mathrm{CH}_{4}$ of a defined quantity of the organic substrate occurs as follows: (i) over a period of 45 days, $50 \%$ of the total volume of the gas is produced in 10 days with a maximum between the $10^{t h}$ and $20^{t h}$ day, (ii) the process of anaerobic digestion continues from the 10 th to the $45^{\text {th }}$ day. This result is in agreement with the literature, which reports that the average time of anaerobic digestion varies between 10 and 15 days [21]. After 45 days of methanation in a temperature range of 27 to $35^{\circ} \mathrm{C}$ (mesophilic), in this experiment, a minimum biogas flow rate of $0.73 \mathrm{Nm}^{3} \cdot \mathrm{d}^{-1}$, a maximum flow rate of $2.49 \mathrm{Nm}^{3} . \mathrm{d}^{-1}$, i.e. an average daily production of $2.05 \mathrm{Nm}^{3} \cdot \mathrm{d}^{-1}$. Future work will consider the optimization of this production by controlling the dilution rate profile.

Table (II) provides the results of the characterization of the physico-chemical parameters. The carbon-nitrogen ratio is about 21.4.

From these data, the initial values of the states is calculated from [20], [22], and [23]. The values of the states at initial time are given in Table III and Table IV. From all these data, the model simulation can be performed and its parameters are then identified.

\section{A. Adjustment of model parameters}

First, the classification of the model parameters according to their influence on the outputs is carried out as described in Section III-B.

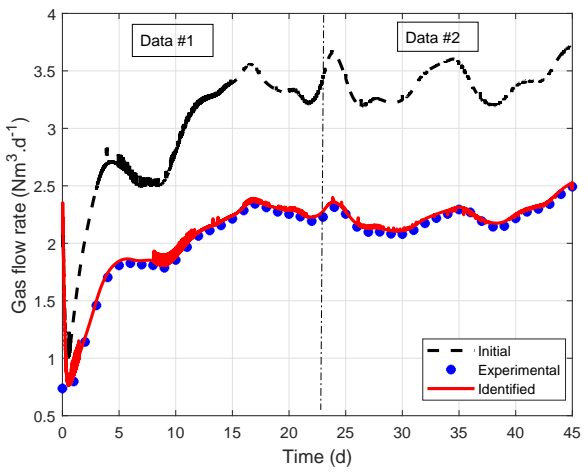

Fig. 4. Gas flow rate evolution versus time.

TABLE II

BIOGAS PRODUCTIVITY OF COW DUNG

\begin{tabular}{|c|c|c|}
\hline Description & Unit & Cow dung \\
\hline MS & $(\%)$ & 57 \\
\hline MO & $(\%)$ & 54 \\
\hline C & $(\% M S)$ & 31 \\
\hline N & $(\% M S)$ & 1.46 \\
\hline COD & $\left(\right.$ kgCOD.m $\left.{ }^{-3}\right)$ & 57.37 \\
\hline VFA & $\left(\right.$ kgCOD.m $\left.{ }^{-3}\right)$ & 2.035 \\
\hline pH & - & 7.4 \\
\hline Ratio (C/N) & - & 21.40 \\
\hline
\end{tabular}

TABLE III

SOLUble COMPONENTS VALUES $\left({ }^{\mathrm{a}}\right.$ ESTIMATED FROM [23], ${ }^{\mathrm{b}}$ EsTiMATED FROM [22]).

\begin{tabular}{|c|c|c|}
\hline Description & Value & Unit \\
\hline Monosacharides & $5.00^{\mathrm{a}}$ & $\mathrm{kgCOD} \cdot \mathrm{m}^{-3}$ \\
\hline Total valerate & 0.125 & $\mathrm{kgCOD} \cdot \mathrm{m}^{-3}$ \\
\hline Total butyrate & 0.065 & $\mathrm{kgCOD} \cdot \mathrm{m}^{-3}$ \\
\hline Total propinate & 0.132 & $\mathrm{kgCOD} \cdot \mathrm{m}^{-3}$ \\
\hline Total acetate & 0.215 & $\mathrm{kgCOD} \cdot \mathrm{m}^{-3}$ \\
\hline Carbohydrates & $18^{\mathrm{b}}$ & $\mathrm{kgCOD} \cdot \mathrm{m}^{-3}$ \\
\hline Proteins & $31^{\mathrm{b}}$ & $\mathrm{kgCOD} \cdot \mathrm{m}^{-3}$ \\
\hline Lipids & $1.7^{\mathrm{b}}$ & $\mathrm{kgCOD} \cdot \mathrm{m}^{-3}$ \\
\hline Particulate inerts & $35.3^{\mathrm{b}}$ & $\mathrm{kgCOD} \cdot \mathrm{m}^{-3}$ \\
\hline
\end{tabular}

TABLE IV

Degraders initial VALUES ( ${ }^{\mathrm{a}}$ ESTIMATED FROM [22]).

\begin{tabular}{|c|c|c|}
\hline Description & Value & Unit \\
\hline Acetate degraders & $1.2^{\mathrm{a}}$ & $\mathrm{kgCOD} \cdot \mathrm{m}^{-3}$ \\
\hline Hydrogen degraders & $0.5^{\mathrm{a}}$ & $\mathrm{kgCOD} \cdot \mathrm{m}^{-3}$ \\
\hline Sugar degraders & $0.27^{\mathrm{a}}$ & $\mathrm{kgCOD} \cdot \mathrm{m}^{-3}$ \\
\hline Amino acid degaders & $0.78^{\mathrm{a}}$ & $\mathrm{kgCOD} \cdot \mathrm{m}^{-3}$ \\
\hline LCFA degraders & $0.15^{\mathrm{a}}$ & $\mathrm{kgCOD} \cdot \mathrm{m}^{-3}$ \\
\hline Valerate and butyrate degaders & $0.28^{\mathrm{a}}$ & $\mathrm{kgCOD} \cdot \mathrm{m}^{-3}$ \\
\hline Propinate degraders & $0.09^{\mathrm{a}}$ & $\mathrm{kgCOD} \cdot \mathrm{m}^{-3}$ \\
\hline
\end{tabular}


The sensitivity analysis is performed for the dilution profile described on Section V. The model parameters are in this case fixed either to values from literature or for values given by default in the ADM1 model. Some results of the sensitivy analysis are given in Table V. For example, it can be noticed that the composite substrate concentration, denoted $X_{c}$, is extremely sensitive to the change of the decay constant $k_{d i s}$, whereas outputs COD concentration, VFA concentration, and gas flow rate are less sensitive to the change of this parameter (but are still sensitive). $X_{c}$, COD and VFA concentrations are not sensitive to the variation of the stochiometric parameter $f_{x i, x c}$, on the contrary to gas flow rate which is very sensitive to this parameter. Parameter $f_{x i, x c}$ is the yield of desintegration of $X_{c}$ into inerte soluble $S_{I}$ (see Fig. 2). In general, $X_{c}$ is obviously very sensitive to variation of $f_{x i, x c}$. However, for the range of the considered dilution rate, and in the operation conditions for which the sensitivity analysis was performed, it besomes less important than the other parameters. It is thus important to emphasis that the result of the sensitivity analysis depends on the considered operation conditions.

TABLE V

SENSITIVITY OF ADM1 MODEL PARAMETERS ON STATE VARIABLES

\begin{tabular}{|c|c|c|c|c|}
\hline Parameters & Xc & COD & VFA & Gas flow \\
\hline$k d i s$ & +++ & + & + & + \\
\hline$f_{x i, x c}$ & 0 & 0 & 0 & ++ \\
\hline$f_{x i, x c}$ & 0 & 0 & 0 & ++ \\
\hline$k_{m, p r}$ & 0 & 0 & +++ & 0 \\
\hline$k_{m, a c}$ & 0 & +++ & +++ & +++ \\
\hline
\end{tabular}

From the sensitivity analysis, 7 parameters among the 105 model parameters are found as the most influential parameters on the outputs. As mentionned previously, only the kinetic parameters are selected to be identified.

The parameters to be identified are: the decay constant (denoted $k_{d i s}$ ), and the parameters describing the kinetics related to the absorption of butyrate, propionate and acetate. The three latter kinetics include limitation and inhibitory effects. Consequently, the paramaters invloved in these kinetics are the maximum absorption rate for butyrate (denoted $k_{m, c 4}$ ), propionate (denoted $k_{m, p r o}$ ), and acetate (denoted $k_{m, a c}$ ); the associated half-saturation coefficients (denoted $K_{S, c 4}, K_{S, p r o}$ and $K_{S, a c}$ respectively). The coefficients describing the inhibitory effects are not identified since the considered dilution profile does not lead the system to be operated in the inhibition conditions.

All the other parameters of the ADM1 model (excluding the 7 above mentionned ones) will be fixed to their values from litterature and more specifically according to [9].

The 7 parameters $k_{d i s}, k_{m, c 4}, k_{m, p r o}, k_{m, a c}, K_{S, c 4}, K_{S, p r o}$ and $K_{S, a c}$ are identified to obtain the best fit to the experimental data. The fminsearch function of the Optimization toolbox of Matlab is used. Other optimization algorithms were tested with similar results. The optimization algorithm was initialized with initial values from the default values of the parameters of the ADM1 model.
The measured data is split into two sets. First set, denoted Data \#1, corresponding to the measured data from time $=0$ to time $=22$ days, is used for the identification. Second set, denoted Data \#2, from time $=22$ days to time $=45$ days, is used for the model validation.

The adjusted parameters are shown in Table (VI). It can be notices that for some parameters, the identified values are very close to their initial value (e.g. $K_{S, a c}$ ), whereas they can be very different (e.g. $K_{m, c 4}$ ). However, all the obtained values are in accordance with the range of varation of these parameters reported in the literature.

TABLE VI ADJUSTMENT OF THE MODEL PARAMETERS.

\begin{tabular}{|c|c|c|}
\hline Parameter & Initial Value & Identified value \\
\hline$k_{d i s}$ & 0.5 & 0.21 \\
\hline$K_{m, c 4}$ & 20 & 7.0 \\
\hline$K_{m, a c}$ & 8 & 6.289 \\
\hline$K_{m, p r o}$ & 12 & 5.5 \\
\hline$K_{S, a c}$ & 0.15 & 0.137 \\
\hline$K_{S, c 4}$ & 0.2 & 0.35 \\
\hline$K_{S, p r o}$ & 0.1 & 0.392 \\
\hline
\end{tabular}

\section{B. Model validation}

The predicted outputs with the identified parameters are illustrated by Fig. 4 to Fig. 6.These figures provide also the outputs with initial guess of the parameters values and the measured data. It is recalled that only data form the set Data \#1 are used for identification, whereas data from the set Data \#2 are used for validation. It can be noticed an agreement between predicted and measured data. Consequently, the obtained model seems to provide a good prediction of the system behavior.

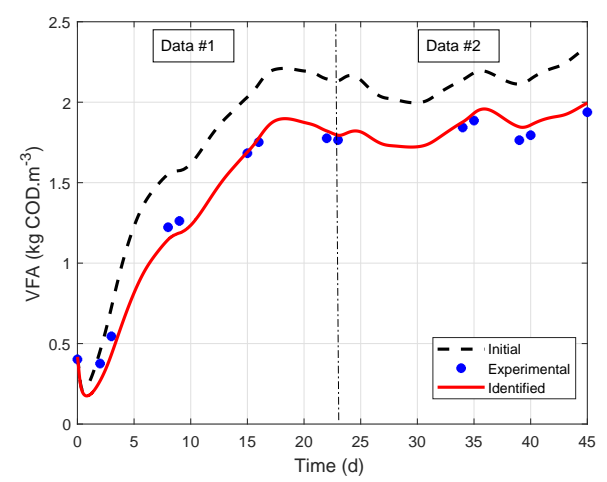

Fig. 5. VFA concentration evolution versus time.

\section{CONCLUSION}

In the present study, the ADM1 modeling of an exprimental continuous biodigestor was considered. An identification procedure was proposed based on a sensitivity analysis of the outputs with respect to the parameter variations. Only 7 parameters among the 105 ADM1 model parameters were identified, whereas the other parameters were fixed to their 


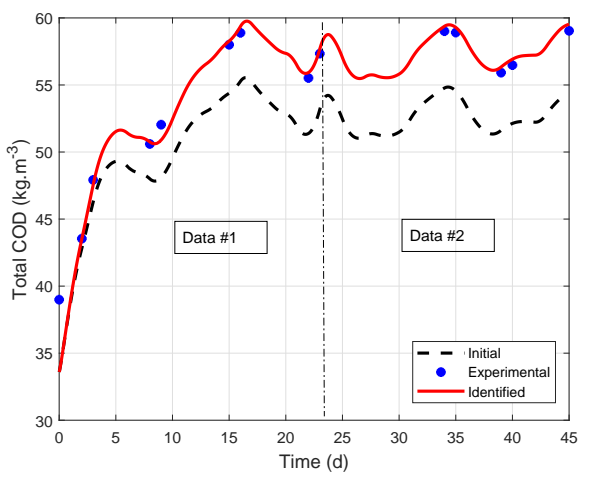

Fig. 6. COD concentration evolution versus time.

value from literature. Measured data of biogas production, VFA and COD concentrations were compared to the ones predicted by the obtained model, highlighting the performance of the obtained model. The ADM1 model is still a high-order complex model. Ongoing research concerns the developement of a reduced model for the system as reported in the literature [10], [24]. The ADM1 model will be used as a reference model since real-life experiments are time demanding. Based on the reduced model, estimation and control strategies will be investigated, based on the gas flow rate, to monitor and control the biogas production so that the process operation is optimized.

\section{REFERENCES}

[1] K. Kiyasudeen, M. H. Ibrahim, S. Quaik, and S. A. Ismail, "An introduction to anaerobic digestion of organic wastes," in Prospects of organic waste management and the significance of earthworms. Springer, 2016, pp. 23-44.

[2] J. De Vrieze, "The next frontier of the anaerobic digestion microbiome: from ecology to process control," Environmental Science and Ecotechnology, p. 100032, 2020.

[3] J. Mata-Alvarez, S. Macé, and P. Llabres, "Anaerobic digestion of organic solid wastes. an overview of research achievements and perspectives," Bioresource technology, vol. 74, no. 1, pp. 3-16, 2000.

[4] P. Rivas-García, J. Botello-Álvarez, L. Miramontes-Martínez, J. CanoGómez, and R. Rico-Martínez, "New model of hydrolysis in the anaerobic co-digestion of bovine manure with vegetable waste: Modification of anaerobic digestion model no. 1," Revista Mexicana de Ingeniería Química, vol. 19, no. 1, pp. 109-122, 2020.

[5] M. Perrier and D. Dochain, "Evaluation of control strategies for anaerobic digestion processes," International journal of adaptive control and signal processing, vol. 7, no. 4, pp. 309-321, 1993.

[6] L. Mailleret, O. Bernard, and J.-P. Steyer, "Robust regulation of anaerobic digestion processes," Water Science and Technology, vol. 48, no. 6, pp. 87-94, 2003.

[7] K. Solon, X. Flores-Alsina, K. V. Gernaey, and U. Jeppsson, "Effects of influent fractionation, kinetics, stoichiometry and mass transfer on ch4, h2 and co2 production for (plant-wide) modeling of anaerobic digesters," Water Science and Technology, vol. 71, no. 6, pp. 870-877, 2015.

[8] O. Bernard, Z. Hadj-Sadok, D. Dochain, A. Genovesi, and J.-P. Steyer, "Dynamical model development and parameter identification for an anaerobic wastewater treatment process," Biotechnology and bioengineering, vol. 75, no. 4, pp. 424-438, 2001.

[9] D. J. Batstone, J. Keller, I. Angelidaki, S. Kalyuzhnyi, S. Pavlostathis, A. Rozzi, W. Sanders, H. Siegrist, and V. Vavilin, "The iwa anaerobic digestion model no 1 (adm1)," Water Science and technology, vol. 45, no. 10 , pp. $65-73,2002$.
[10] S. Hassam, E. Ficara, A. Leva, and J. Harmand, "A generic and systematic procedure to derive a simplified model from the anaerobic digestion model no. 1 (adm1)," Biochemical Engineering Journal, vol. 99, pp. 193-203, 2015.

[11] G. Ekama, P. Dold, and G. v. R. Marais, "Procedures for determining influent cod fractions and the maximum specific growth rate of heterotrophs in activated sludge systems," Water Science and Technology, vol. 18, no. 6, pp. 91-114, 1986.

[12] K. Bułkowska, I. Białobrzewski, Z. M. Gusiatin, E. Klimiuk, and T. Pokój, "Adm1-based modeling of anaerobic codigestion of maize silage and cattle manure-calibration of parameters and model verification (part ii)/modelowanie kofermentacji kiszonki kukurydzy i obornika bydlęcego za pomocą adm1-kalibracja i weryfikacja modelu (część ii)," Archives of Environmental Protection, vol. 41, no. 3, pp. 20-27, 2015.

[13] M. Lübken, M. Wichern, M. Schlattmann, A. Gronauer, and H. Horn, "Modelling the energy balance of an anaerobic digester fed with cattle manure and renewable energy crops," Water research, vol. 41, no. 18, pp. 4085-4096, 2007.

[14] S. Pavlostathis and E. Giraldo-Gomez, "Kinetics of anaerobic treatment: a critical review," Critical Reviews in Environmental Science and Technology, vol. 21, no. 5-6, pp. 411-490, 1991.

[15] R. Girault, G. Bridoux, F. Nauleau, C. Poullain, J. Buffet, J.-P. Steyer, A. Sadowski, and F. Béline, "A waste characterisation procedure for adm1 implementation based on degradation kinetics," Water Research, vol. 46, no. 13, pp. 4099-4110, 2012.

[16] V. Vavilin, B. Fernandez, J. Palatsi, and X. Flotats, "Hydrolysis kinetics in anaerobic degradation of particulate organic material: an overview," Waste management, vol. 28, no. 6, pp. 939-951, 2008.

[17] P. Biernacki, S. Steinigeweg, A. Borchert, F. Uhlenhut, and A. Brehm, "Application of anaerobic digestion model no. 1 for describing an existing biogas power plant," Biomass and Bioenergy, vol. 59, pp. 441447, 2013.

[18] C. Rosén and U. Jeppsson, "Aspects on adm1 implementation within the bsm2 framework," Department of Industrial Electrical Engineering and Automation, Lund University, Lund, Sweden, pp. 1-35, 2006.

[19] B. Petersen, P. A. Vanrolleghem, K. Gernaey, and M. Henze, "Evaluation of an asm1 model calibration procedure on a municipal-industrial wastewater treatment plant," Journal of Hydroinformatics, vol. 4, no. 1, pp. 15-38, 2002.

[20] D. J. Batstone, J. Keller, and L. Blackall, "The influence of substrate kinetics on the microbial community structure in granular anaerobic biomass," Water Research, vol. 38, no. 6, pp. 1390-1404, 2004.

[21] R. Moletta, "Technologies de la méthanisation de la biomasse déchets ménagers et agricoles,' La méthanisation, in French., p. 177, 2011.

[22] D. Page, K. Hickey, R. Narula, A. Main, and S. Grimberg, "Modeling anaerobic digestion of dairy manure using the iwa anaerobic digestion model no. 1 (adm1)," Water Science and Technology, vol. 58, no. 3, pp. 689-695, 2008.

[23] U. Zaher and S. Chen, "Interfacing the iwa anaerobic digestion model no. 1 (adm1) with manure and solid waste characteristics," Proceedings of the Water Environment Federation, vol. 1, no. 1, pp. 3162-3175, 2006.

[24] C. García-Diéguez, O. Bernard, and E. Roca, "Reducing the anaerobic digestion model no. 1 for its application to an industrial wastewater treatment plant treating winery effluent wastewater," Bioresource technology, vol. 132, pp. 244-253, 2013. 